\title{
Manajemen Persampahan di Kecamatan Rimbo Tengah Kabupaten Bungo
}

\author{
Zepa Anggraini ${ }^{1 *}$, Joko Susanto $^{2}$ \\ ${ }^{1}$ Sekolah Tinggi Ilmu Administrasi Setih Setio Muara Bungo, Jambi, Indonesia \\ 2 Sekolah Tinggi Ilmu Administrasi Setih Setio Muara Bungo, Jambi, Indonesia \\ ${ }^{1}$ zepaanggraini@gmail.com*; ${ }^{2}$ jokosusantoo251@ gmail.com \\ * corresponding author
}

\section{ARTICLE INFO}

\section{Article history}

Received 2019-11-28

Revised 2019-12-02

Accepted 2019-12-09

\section{Keywords}

Management,

Management Function,

Solid Waste, Waste

Management,

Community Participation

Environment,

Central Rimbo Subdistrict.

\section{$A B S T R A C T$}

The Bungo Regency Environmental Agency as the prime mover in responsible waste management and encourages the community to be involved in waste management, that waste problems in Rimbo Tengah District Bungo District will not be solved if it only depends on the government alone, and therefore needs support and community participation in waste management. Community participation is expected to start from $3 R$, namely Reuse, Reduce, and Recycle. The purpose of this study is to examine in depth related to the implementation of waste management in the District of Central Rimbo Bungo District. The method used in this research is descriptive method with a qualitative approach. As for the informants in this study amounted to eight people consisting of five informants from the Bungo Regency Environmental Agency and three informants from the local community who are in Central Rimbo District. The data collection techniques are through observation, interviews and document review. The results showed that waste management in Rimbo Tengah Subdistrict, Bungo District by the Bungo District Environmental Agency had been implemented well. This can be seen from the application of management perspective which plays an important role in the whole process of waste management starting from planning, organizing, implementing / mobilizing and controlling. However, in the process of waste management by the Bungo Regency Environmental Agency, there are still some problems and shortcomings in the management process, namely the implementation or mobilization and supervision processes.

\section{PENDAHULUAN}

Lingkungan hidup yang baik, bersih dan sehat merupakan hak asasi setiap Warga Negara Indonesia sebagaimana diamanatkan dalam pasal 28 H UUD 1945. Kehidupan manusia tidak terlepas dari interaksi dengan lingkungan sekitarnya. Menurut UU No. 23 Tahun 1997 tentang Pengelolaan Lingkungan Hidup dijelaskan bahwa, lingkungan hidup adalah kesatuan ruang dengan semua benda dan kesatuan makhluk hidup termasuk di dalamnya manusia dan perilakunya yang melangsungkan perikehidupan dan kesejahteraan manusia serta makhluk hidup lainnya.

Pencemaran lingkungan yang semakin meningkat disebabkan oleh berbagai hal, seperti bertambahnya populasi manusia yang mengakibatkan meningkatnya jumlah sampah yang dibuang. Hal ini diperburuk dengan kurang memadainya tempat dan lokasi pembuangan sampah, kurangnya kesadaran dan kemauan masyarakat dalam mengelola dan membuang sampah, masih kurangnya pemahaman masyarakat tentang manfaat sampah, serta keengganan masyarakat memanfaatkan kembali sampah dalam mengelolanya, karena sampah dianggap sebagai sesuatu yang kotor, bau dan harus dibuang ataupun gengsi. Berbagai hal tersebut menyebabkan menurunnya kualitas lingkungan yang berdampak negatif bagi masyarakat.

Secara umum masyarakat mengenal sampah sebagai sesuatu benda yang dihasilkan dari berbagai benda yang telah digunakan dan tidak diperlukan lagi oleh manusia. Sedangkan menurut Mochtar M. (1987:55) sampah adalah sesuatu yang tidak digunakan, tidak dipakai, tidak disenangi, atau sesuatu yang dibuang yang berasal dari kegiatan manusia dan tidak terjadi dengan sendirinya.

Permasalahan tentang lingkungan hidup yang cukup perlu khalayak perbaiki adalah tentang pengelolaan sampah, hal ini dikarenakan dengan pertambahan penduduk dan perubahan pola konsumsi masyarakat menimbulkan bertambahnya volume, jenis, dan karakteristik sampah yang semakin beragam. Untuk mengantisipasi persoalan tersebut, maka salah satu hal yang dilakukan oleh pemerintah adalah membuat Undang-Undang Nomor 18 Tahun 2008 tentang pengelolaan sampah, karena dalam pengelolaan sampah diperlukan kepastian hukum, kejelasan tanggung jawab dan kewenangan pemerintahan daerah, serta 
peran masyarakat dan dunia usaha sehingga pengelolaan sampah dapat berjalan secara proporsional, efektif, dan efisien.

Persoalan sampah tidak henti-hentinya untuk dibahas, karena berkaitan dengan pola hidup serta budaya masyarakat itu sendiri. Olehnya penanggulangan sampah bukan hanya urusan pemerintah semata akan tetapi penanganannya membutuhkan partisipasi masyarakat secara luas.

Berdasarkan artikel yang ditulis oleh Mareza pada tanggal 07 November 2019 di berita online Tribunjambi.com, Muara Bungo, bahwa di Kabupaten Bungo, sekitar 143 ton sampah dihasilkan setiap harinya. Perkiraan itu dihitung dari jumlah penduduk di 17 kecamatan yang ada di Kabupaten Bungo. Kepala Dinas Lingkungan Hidup Kabupaten Bungo, Prasetyo melalui Kabid Kebersihan, Zulkarnain mengestimasikan, setiap orang di Kabupaten Bungo membuang sampah sekitar 0,4 kilogram setiap harinya. Dengan jumlah penduduk 357.860 jiwa, diperkirakan total sampah yang ditimbun setiap hari sekitar 143 ton. Estimasinya, setiap orang membuang sampah sekitar 0,4 kilogram per harinya, dikalikan jumlah penduduk sebanyak 357.860 jiwa. Totalnya sekitar 143 ton per hari. Dirincikannya, produksi sampah terbanyak terjadi di sekitaran Kota Muara Bungo, sekitar 75 ton. Jumlah tersebut merupakan sampah yang terkumpul dari empat kecamatan, yaitu Pasar Muara Bungo, Rimbo Tengah, Bungo Dani, dan Bathin III.

Sebagai leading sector dalam pengelolaan persampahan di Kabupaten Bungo, Dinas Lingkungan Hidup (DLH) seharusnya lebih aktif dalam penanganan sampah seiring dengan bertambahnya jumlah penduduk di Kabupaten Bungo setiap tahunnya, juga berakibat terhadap naiknya jumlah rata-rata produksi sampah khususnya di Kecamatan Rimbo Tengah. Permasalahan sampah di Kabupaten Bungo tidak bisa dianggap sepele atau hanya dipandang sebelah mata saja, khususnya masalah sampah yang ada di kecamatan Rimbo Tengah Kabupaten Bungo harus bisa dikelola dengan baik, karena apa bila sampah yang tidak dikelola dengan baik dapat menyebabkan lingkungan menjadi kotor dan menyebabkan pendangkalan sungai yang mengakibatkan timbulnya banjir. Selain itu, sampah dapat mengakibatkan meningkatnya penyebaran penyakit, bau menyengat karena sampah lama mengendap ditempat pembuangan sampah karena tidak diangkut-angkut oleh petugas, dan lain-lain sehingga mengganggu kenyamanan dan kesehatan khususnya di Kecamatan Rimbo Tengah.

Terkait tentang pengelolaan sampah, secara spesifik di Kabupaten Bungo sendiri sudah diatur di dalam peraturan daerah Kabupaten Bungo Nomor 6 tahun 2015 Tentang Pengelolaan sampah. Berdasarkan peraturan daerah Kabupaten Bungo Nomor 6 pasal 4 tahun 2015 Tentang Pengelolaan sampah, bahwa tujuan dari pengelolaan sampah adalah:

1. Mengurangi kuantitas dan dampak yang ditimbulkan oleh sampah;

2. Meningkatkan kesehatan masyarakat;

3. Meningkatkan kualitas lingkungan hidup;

4. Menjadikan sampah sebagai sumber daya.

Agar tercapainya tujuan dari pengelolaan sampah tersebut, maka perlu manajemen yang baik dalam pengelolaannya yang dilakukan oleh dinas terkait yaitu Dinas Lingkungan Hidup Kabupaten Bungo, yaitu dimulai dari perencanaan yaitu terkait dengan merencanakan tentang penetapan tujuan dan cara mencapai tujuan terkait dengan pengelolaan sampah. Kemudian pengorganisasian, fungsi perencanaan adalah pengaturan sumber daya manusia dan sumber daya fisik yang dimiliki agar bisa menjalankan rencanarencana yang sudah diputuskan untuk mencapai tujuan yang diinginkan, fungsi pengorganisasian mengelompokkan semua orang, alat, tugas dan wewenang yang ada dijadikan satu kesatuan yang kemudian digerakkan melaksanakan apa yang sudah direncanakan sebelumnya. Selanjutnya adalah directing atau fungsi pengarahan adalah upaya untuk menciptakan suasana kerja dinamis, sehat agar kinerjanya lebih efektif dan efisien. Dan yang terakhir adalah fungsi pengendalian atau pengawasan, fungsi pengendalian adalah upaya untuk menilai suatu kinerja yang berpatokan kepada standar yang telah dibuat, juga melakukan perbaikan apabila memang dibutuhkan.

Berdasarakan uraian di atas, maka peneliti tertarik untuk melakukan penelitian ini yakni terkait dengan manajemen persampahan di Kecamatan Rimbo Tengah Kabupaten Bungo. Maka dari itu peneliti merumuskan pertanyaan penelitian yaitu bagaimanakah manajemen persampahan di Kecamatan Rimbo Tengah Kabupaten Bungo? Oleh karena itu perlu dilakukan penelitian tentang manajemen persampahan, serta manfaat dari pengelolaan sampah bagi masyarakat untuk menjelaskan dan memberikan informasi mengenai permasalahan yang ada sehingga dapat diambil solusi agar manajemen persampahan dapat dilaksanakan secara berkelanjutan baik di lokasi penelitian maupun di tempat lain. Tujuan dilakukannya penelitian ini adalah untuk mengkaji secara mendalam terkait dengan pelaksanaan manajemen persampahan di Kecamatan Rimbo Tengah Kabupaten Bungo, sehingga dapat memberikan rekomendasi untuk keberlanjutan pelaksanaan pengelolaan sampah di lokasi penelitian maupun di tempat lain, karena mengingat 
lingkungan hidup merupakan salah satu bidang utama yang dikembangkan pemerintah untuk meningkatkan kualitas lingkungan hidup yang baik. Begitu juga pemerintah daerah Kabupaten Bungo, yang menjadikan lingkungan hidup sebagai salah satu bidang peningkatan kualitas hidup yang sehat. Sehingga pemerintah melakukan kegiatan sosialisasi penegakan kebijakan pemerintah daerah dalam pengelolaan persampahan.

\section{KAJIAN LITERATUR}

Penelitian terkait dengan pengelolaan sampah ini juga telah dilakukan oleh peneliti-peneliti sebelumnya. Hal yang membedakan antara penelitian ini dengan penelitian terdahulu tersebut secara keseluruhan terdapat persamaan dengan penelitian yang diteliti yaitu untuk mengetahui tentang pengelolaan atau manajemen persampahan. Namun terdapat juga perbedaan penelitian, yaitu perbedaan lokasi dimana peneliti mengambil lokasi di Kecamatan Rimbo Tengah Kabupaten Bungo.

Salah satu penelitian terdahulu yang dilakukan oleh Viradin Yogiesti, dkk (2010) tentang Pengelolaan Sampah Terpadu Berbasis Masyarakat Kota Kediri, hasil penelitian menunjukkan bahwa Pengolahan sampah sudah dilakukan pemerintah setempat sejak tahun 2008. Usaha tersebut dengan membangun unit komposter dengan partisipasi masyarakat. Namun pada aplikasinya masyarakat tidak terlibat secara langsung karena mereka beranggapan pengelolaan persampahan ini adalah tanggung jawab pemerintah Berdasarkan hasil analisis multidimensional scaling (MDS) menghasilkan jenis pengolahan sampah yaitu komposting dan daur ulang kertas. Setelah proses analisis menghasilkan arahan pengelolaan sampah terpadu berbasis masyarakat Kota Kediri sesuai dengan jenis pengolahan sampah yang dipilih masyarakat yaitu komposing dan daur ulang kertas.

Rujukan selanjutnya adalah penelitian yang dilakukan oleh Putri Nilam Sari (2016) tentang Analisis Pengelolaan Sampah Padat Di Kecamatan Banuhampu Kabupaten Agam, hasil penelitian menunjukkan bahwa belum adanya perencanaan khusus dalam pengelolaan sampah karena tidak adanya tempat pengelolaan sampah. Untuk pelaksanaan pengelolaan sampah, di daerah pinggir kota telah terdapat masyarakat yang bekerjasama dengan Kota Bukittinggi dan di daerah pedesaan telah ada masyarakat yang mengelola sampah dengan membuat kompos, tetapi sebagian besar sampah masih dibuang sembarangan. Diperlukan perwakilan BPLH untuk memanajemen pengelolaan sampah di Kecamatan Banuhampu, membuat Peraturan Daerah khusus sampah, pengembangan metode pengelolaan sampah dan sosialisasi kepada masyarakat untuk melaksanakan 3R (Reduce, Reuse, Recycle) sehingga jumlah sampah dapat diminimalisir.

Penelitian selanjutnya dilakukan oleh Mohamad Rizal (2011) tentang Analisis Pengelolaan Persampahan Perkotaan (Sudi kasus pada Kelurahan Boya Kecamatan Banawa Kabupaten Donggala). Hasil penelitian menunjukkan bahwa pengelolaan persampahan di Kota Donggala sudah cukup baik. Beberapa faktor yang mempengaruhi pengelolaan sampah di Kota Donggala adalah partisipasi masyarakat, tingkat pendidikan staf dan jumlah tenaga kebersihan.

Rujukan berikutnya yaitu penelitian yang dilakukan oleh Muchammad Zamzami Elamin, dkk (2018) tentang Analisis Pengelolaan Sampah Pada Masyarakat Desa Disanah Kecamatan Sreseh Kabupaten Sampang. Hasil penelitian menunjukkan bahwa pengelolaan sampah di Desa tersebut masih kurang baik hal ini dikarenakan tidak adanya lahan untuk pembangunan tempat penampungan sementara, fasilitas sarana dan prasarana yang masih belum baik, dan tingkat kesadaran masyarakat yang masih rendah akan pentingnya pengelolaan sampah dengan baik dan benar. Saran yang bisa diberikan adalah dengan melakukan sosialisasi tentang pengelolaan sampah yang baik dan benar, jadwal rutin gotong royong bersih desa dan memasukkan anggaran untuk pembebasan lahan yang akan digunakan untuk tempat penampungan sementara.

Rujukan terakhir yaitu penelitian yang dilakukan oleh Siti Rizka Mulyani, dkk (2018) tentang Manajemen Persampahan di Kota Bukittinggi. Hasil penelitian menunjukkan bahwa pengelolaan persampahan yang dilakukan oleh Pemerintah Kota Bukittinggi telah berjalan dengan baik. Hal itu dapat dilihat dari penerapan perspektif manajemen yang berperan penting dalam keseluruhan proses pengelolaan persampahan mulai dari perencanaan, pengorganisasian, pemberian motivasi dan pengawasan. Namun dalam proses pengelolaan persampahan oleh Pemerintah Kota Bukittinggi ini masih terdapat beberapa masalah dan kekurangan dalam proses manajemennya yaitu pada proses perencanaan, dan pengorganisasian.

\section{Konsep Manajemen}

Manajemen secara umum adalah suatu proses yang terdiri dari perencanaan, pengorganisasian, pengarahan, kepemimpinan, pengendalian dan pengawasan melalui pemanfaatan sumber daya dan sumbersumber lainnya secara efektif dan efisien untuk mencapai tujuan tertentu yang telah ditetapkan.Pengertian 
manajemen menurut Anton Mulyono Aziz dan Maya Irjayanti (2014;5) mendefinisikan bahwa seni manajemen meliputi untuk melihat totalitas dari bagian yang terpisah-pisah serta kemampuan untuk menciptakan gambaran tentang suatu visi.

Menurut Ulber Silalahi $(2011 ; 7)$ mendefisikan bahwa manajemen sebagai proses perencanaan, pengorganisasian, pengatur sumberdaya, pengomunikasian, pemimpinan, pemotivasian, dan pengendalian pelaksanaan tugas-tugas dan penggunaan sumber-sumber untuk mencapai tujuan organisasional secara efektif dan secara efesien.

Sedangkan menurut Lilis Sulastri, mengutip di dalam bukunya Manajemen Sebuah Pengantar (Sejarah, Tokoh, Teori dan Praktik) (2014;14) mendefinisikan bahwa manajemen adalah suatu seni mengatur yang melibatkan proses, cara, dan tindakan tertentu, seperti perencanaan, pengorganisasian, pengerahan dan pengendalian/pengawasan, yang dilakukan untuk menentukan dan mencapai tujuan secara efesien dan efektif dengan dan melalui orang lain.

Menurut G.R Terry(dalamHasibuan, 2014:2), menyatakan bahwa: Manajemen adalah suatu proses khas yang terdiri atas tindakan-tindakan perencanaan, pengorganisasian, pergerakan dan pengendalian untuk menentukan serta mencapai tujuan melalui pemanfaatan sumber daya manusia dan sumber daya lainnya.

\section{Fungsi Manajemen}

George R. Terry,1958 dalam bukunya Principles of Management (Sukarna, 2011: 10) membagi empat fungsi dasar manajemen, yaitu Planning (Perencanaan), Organizing (Pengorganisasian), Actuating (Pelaksanaan) dan Controlling (Pengawasan). Keempat fungsi manajemen ini disingkat dengan POAC.

\section{Planning (Perencanaan)}

George R. Terry dalam bukunya Principles of Management (Sukarna, 2011: 10) mengemukakan tentang Planning sebagai berikut, yaitu: "Planning is the selecting and relating of facts and the making and using of assumptions regarding the future in the visualization and formulation to proposed of proposed activation believed necesarry to accieve desired result". "Perencanaan adalah pemilih fakta dan penghubungan fakta-fakta serta pembuatan dan penggunaan perkiraan-perkiraan atau asumsi-asumsi untuk masa yang akan datang dengan jalan menggambarkan dan merumuskan kegiatan-kegiatan yang diperlukan untuk mencapai hasil yang diinginkan".

\section{Planning (Perencanaan)}

George R. Terry dalam bukunya Principles of Management (Sukarna, 2011: 10) mengemukakan tentang Planning sebagai berikut, yaitu: "Planning is the selecting and relating of facts and the making and using of assumptions regarding the future in the visualization and formulation to proposed of proposed activation believed necesarry to accieve desired result". "Perencanaan adalah pemilih fakta dan penghubungan fakta-fakta serta pembuatan dan penggunaan perkiraan-perkiraan atau asumsi-asumsi untuk masa yang akan datang dengan jalan menggambarkan dan merumuskan kegiatan-kegiatan yang diperlukan untuk mencapai hasil yang diinginkan".

\section{Planning (Perencanaan)}

George R. Terry dalam bukunya Principles of Management (Sukarna, 2011: 10) mengemukakan tentang Planning sebagai berikut, yaitu: "Planning is the selecting and relating of facts and the making and using of assumptions regarding the future in the visualization and formulation to proposed of proposed activation believed necesarry to accieve desired result". "Perencanaan adalah pemilih fakta dan penghubungan fakta-fakta serta pembuatan dan penggunaan perkiraan-perkiraan atau asumsi-asumsi untuk masa yang akan datang dengan jalan menggambarkan dan merumuskan kegiatan-kegiatan yang diperlukan untuk mencapai hasil yang diinginkan".

\section{Controlling (Pengawasan)}

Menurut George R. Terry (Sukarna, 2011: 110) mengemukakan bahwa controlling, yaitu: "Controlling can be defined as the process of determining what is to accomplished, that is the standard, what is being accomplished. That is the performance, evaluating the performance, and if the necessary applying corrective measure so that performance takes place according to plans, that is conformity with the standard". "Pengawasan dapat dirumuskan sebagai proses penentuan apa yang harus dicapai yaitu standard, apa yang sedang dilakukan yaitu pelaksanaan, menilai pelaksanaan, dan bila mana perlu melakukan perbaikan-perbaikan, sehingga pelaksanaan sesuai dengan rencana, yaitu selaras dengan standard (ukuran)". 


\section{Sampah}

Undang-Undang Pengelolaan Sampah Nomor 18 tahun 2008 menyatakan sampah adalah sisa kegiatan sehari-hari manusia dan/atau dari proses alam yang berbentuk padat. Juli Soemirat (1994) berpendapat bahwa sampah adalah sesuatu yang tidak dikehendaki oleh yang punya dan bersifat padat. Azwar (1990) mengatakan yang dimaksud dengan sampah adalah sebagian dari sesuatu yang tidak dipakai, tidak disenangi atau sesuatu yang harus dibuang yang umumnya berasal dari kegiatan yang dilakukan manusia (termasuk kegiatan industri) tetapi bukan biologis karena kotoran manusia (human waste) tidak termasuk kedalamnya. Manik (2003) mendefinisikan sampah sebagai suatu benda yang tidak digunakan atau tidak dikehendaki dan harus dibuang, yang dihasilkan oleh kegiatan manusia.

Berdasarkan peraturan daerah Kabupaten Bungo Nomor 6 pasal 4 tahun 2015 Tentang Pengelolaan sampah, bahwa tujuan dari pengelolaan sampah adalah:

1. Mengurangi kuantitas dan dampak yang ditimbulkan oleh sampah;

2. Meningkatkan kesehatan masyarakat;

3. Meningkatkan kualitas lingkungan hidup;

4. Menjadikan sampah sebagai sumber daya.

\section{Pengelolaan sampah}

Berdasarkan Undang-Undang Nomor 18 pasal 1 Tahun 2008 tentang Pengelolaan Sampah, pengelolaan sampah adalah kegiatan sistematis, menyeluruh, dan berkesinambungan yang meliputi pengurangan dan penanganan sampah. Kemudian dalam pasal 22 tentang kegiatan pengelolaan sampah meliputi:

1. Pemilahan dalam bentuk pengelompokan dan pemisahan sampah sesuai dengan jenis, jumlah, dan/atau sifat sampah;

2. Pengumpulan dalam bentuk pengambilan dan pemindahan sampah dari sumber sampah ke tempat penampungan sementara atau tempat pengolahan sampah terpadu;

3. Pengangkutan dalam bentuk membawa sampah dari sumber dan/atau dari tempat penampungan sampah sementara atau dari tempat pengolahan sampah terpadu menuju tempat pemrosesan akhir.

4. Pengolahan dalam bentuk karakteristik, komposisi dan jumlah sampah.

5. Pemrosesan akhir sampah dalam bentuk pengembalian sampah dan/atau residu hasil pengolahan sebelumnya ke media lingkungan secara umum.

\section{Metode Pengelolaan Sampah}

Menurut Wahid Iqbal dan Nurul C. (2009:279-280) tentang tahap pengelolaan dan pemusnahan sampah dilakukan dengan 2 metode:

1. Metode yang memuaskan

a. Metode Sanitary Landfill (lahan urug saniter), yaitu pemusnahan sampah dengan membuat lubang di tanah kemudian sampah dimasukkan dan ditimbun dengan tanah sebagai lapisan penutup lalu dipadatkan. Cara ini memerlukan persyaratan harus tersedia tempat yang luas, tersedia tanah untuk menimbunnya, dan tersedia alat-alat besar.

b. Inceneration (dibakar), yaitu memusnahkan sampah dengan jalan membakar di dalam tungku pembakaran khusus. Manfaat sistem ini volume sampah dapat diperkecil sampai satu per tiga, tidak memerlukan ruang yang luas, panas yang dihasilkan dapat digunakan sebagai sumber uap, dan pengelolaan dapat dilakukan secara terpusat dengan jadwal jam kerja. Adapun akibat penerapan metode ini adalah memerlukan biaya besar, lokasi pembuangan pabrik sulit didapat karena keberadaan penduduk, dan peralatan-peralatan yang digunakan dalam incenerasi.

c. Composting (dijadikan pupuk), yaitu mengelola sampah menjadi pupuk kompos; khususnya untuk sampah organik.

2. Metode yang tidak memuaskan.

a. Metode Open Dumping, yaitu sistem pembuangan sampah yang dilakukan secara terbuka. Hal ini akan menjadi masalah jika sampah yang dihasilkan adalah sampah organik yang membusuk karena menimbulkan gangguan pembauan dan estetika serta menjadi sumber penularan penyakit.

b. Metode Dumping in Water, yaitu pembuangan sampah ke dalam air. Hal ini akan dapat mengganggu rusaknya ekosistem air. Air akan menjadi kotor, warnanya berubah, danmenimbulkan sumber penyakit yang ditularkan melalui air (water borne disease). 
c. Metode Burning on premises (individual inceneration) yaitu pembakaran sampah dilakukan di rumah-rumah tangga.

\section{METODE PENELITIAN}

Penelitian ini merupakan penelitian deskriptif dengan pendekatan kualitatif. Dalam penelitian ini peneliti mengambil informan dengan menggunakan teknik porposive sampling. Teknik porposive sampling yaitu untuk menentukan sampel/informan penelitian dengan beberapa pertimbangan tertentu yang bertujuan agar data yang diperoleh nantinya bisa lebih representatif. Adapun yang menjadi informan dalam penelitian ini berjumlah 8 (delapan) orang yaitu terdiri dari 5 (lima) informan dari pihak Dinas Lingkungan Hidup Kabupaten Bungo dan 3 (tiga) informan dari pihak masyarakat setempat yang berada di Kecamatan Rimbo Tengah. Informan tersebut dipilih karena peneliti memerlukan informasi yang dapat mewakili karakteristik populasi, maka peneliti mengambil delapan orang informan sebagai objek penelitian karena informan tersebut dirasa mampu mewakili karakteristik populasi yang diinginkan. Teknik pengumpulan data pada penelitian ini yaitu observasi, wawancara, dan telaah dokumen. Wawancara ini diupayakan untuk memperoleh data sebanyak mungkin dari pegawai Dinas Lingkungan Hidup Kabupaten Bungo terkait dengan pengelolaan persampahan yang dilakukan sehingga data-data yang nanti muncul adalah pernyataanpernyataan yang dikemukakan oleh para pegawai mengenai pelaksanaan pengelolaan persampahan di Kecamatan Rimbo Tengah. Sedangkan bentuk metode observasi yang peneliti gunakan dalam penelitian ini adalah metode observasi biasa. Dengan kata lain peneliti melihat sendiri bagaimana Pengelolaan Persampahan Oleh Pemerintah Kabupaten Bungo. Dokumentasi diperoleh peneliti dari studi kepustakaan dan dari media elektronik sebagai data sekunder dalam penelitian ini. Hal ini dilakukan untuk melengkapi analisis data serta memperkuat kesimpulan yang di dapat serta laporan penelitian yang berkaitan dengan Pengelolaan Persampahan Oleh Pemerintah Kabupaten Bungo. Teknik analisis data yang digunakan dalam penelitian ini dimulai dari seluruh data yang telah terkumpul, melalui observasi, wawancara, dan dokumentasi dituliskan dalam catatan lapangan selama melakukan penelitian. Data-data yang telah diperoleh berbagai sumber kemudian dideskripsikan dan interpretasikan. Model penelitian kualitatif dalam penelitian ini yaitu Fenomenologi. Penelitian fenomenologi dapat dimulai dengan memperhatikan dan menelaah fokus fenomena yang akan diteliti, yang melihat berbagai aspek subjektif dari perilaku objek. Selanjutnya, peneliti melakukan penggalian data berupa bagaimana pemaknaan objek dalam memberikan arti terhadap fenomena yang terkait. Penggalian data tersebut dilakukan dengan melakukan wawancara yang mendalam kepada objek atau informan di dalam penelitian, serta dengan melakukan observasi secara langsung mengenai bagaimana objek penelitian menginterpretasikan pengalamannya kepada orang lain.

\section{HASIL DAN PEMBAHASAN}

Pada umumnya masyarakat mengenal sampah sebagai sesuatu benda yang dihasilkan dari berbagai benda yang telah digunakan dan tidak diperlukan lagi oleh manusia. Sehingga sampah dapat diartikan sebagai sesuatu yang tidak digunakan, tidak dipakai, tidak disenangi oleh manusia, atau sesuatu yang dibuang yang berasal dari kegiatan manusia dan tidak terjadi dengan sendirinya.

Peran serta masyarakat dirasakan masih minim. Hal yang paling mempengaruhi rendahnya partisipasi masyarakat adalah tidak adanya lahan pengelolaan sampah. Peran serta masyarakat diharapkan mulai dari 3R. Rendahnya praktek pemanfaatan sampah (3R) juga menjadi permasalahan dalam pengelolaan persampahan yang ada di Kecamatan Rimbo Tengah. Adapun 3R yang dimaksud yaitu Reuse berarti menggunakan kembali sampah yang masih dapat digunakan untuk fungsi yang sama ataupun fungsi lainnya. Reduce berarti mengurangi segala sesuatu yang mengakibatkan sampah. Recycle berarti mengolah kembali (daur ulang) sampah menjadi barang atau produk baru yang bermanfaat.

Pengelolaan Persampahan di Kecamatan Rimbo Tengah di bawah pertanggung jawaban Dinas Lingkungan Hidup Kabupaten Bungo pada bidang kebersihan. Pengelolaan persampahan diselenggarakan berdasakan asas tanggung jawab, asas berkelanjutan, asas manfaat, asas keadilan, asas kesadaran, asas kebersamaan, asas keselamatan, asas keamanan, dan asas nilai ekonomi. Berdasarkan peraturan daerah Kabupaten Bungo Nomor 6 pasal 4 tahun 2015 Tentang Pengelolaan sampah, bahwa tujuan dari pengelolaan sampah adalah:

1. Mengurangi kuantitas dan dampak yang ditimbulkan oleh sampah;

2. Meningkatkan kesehatan masyarakat;

3. Meningkatkan kualitas lingkungan hidup;

4. Menjadikan sampah sebagai sumber daya. 
Untuk peningkatan kinerja pengelolaan sampah yang baik, maka penegakan kebijakan pemerintah dalam pengelolaan persampahan dengan tugas pokok dan fungsi menindak warga atau masyarakat yang membuang sampah tidak sesuai dengan tempat dan waktunya dan membuaang sampah sembarangan atau membuang sampah di tempat umum, sehingga dapat mengganggu kenyamanan masyarakat dan ketertiban umum. Dalam menjalankan peraturan daerah Kabupaten Bungo Nomor 6 tahun 2015 Tentang Pengelolaan sampah, Dinas Lingkungan Hidup Kabupaten Bungo bekerjasama dengan Anggota Satpol PP Kabupaten Bungo Berdasarkan Perda Nomor 08 Tahun 2013 mempunyai tugas pokok menegakkan Peraturan Daerah dan Peraturan Bupati memelihara dan menyelenggarakan ketentraman dan ketertiban umum serta perlindungan masyarakat.

Sehingga dalam proses pengelolaan persampahan ini harus diiringi oleh pola manajemen yang baik agar dapat berhasil mencapai tujuannya. Menurut George R. Terry,1958 dalam bukunya Principles of Management (Sukarna, 2011: 10) untuk melihat manajemen suatu pengelolaan maupun kegiatan maka bisa dilihat dari empat fungsi dasar manajemen, yaitu Planning (Perencanaan),Organizing (Pengorganisasian), Actuating (Pelaksanaan) dan Controlling (Pengawasan). Keempat fungsi manajemen ini disingkat ataupun dikenal dengan POAC.

\section{Planning (Perencanaan)}

Untuk mencapai suatu tujuan terutama adalah tujuan dalam pengelolaan sampah, maka perlu persiapan yang matang, terutama terkait dengan proses perencanaan. Perencanaan dapat diartikan sebagai pemilih fakta dan penghubungan fakta-fakta serta pembuatan dan penggunaan perkiraan-perkiraan atau asumsi-asumsi untuk masa yang akan datang dengan jalan menggambarkan dan merumuskan kegiatankegiatan yang diperlukan untuk mencapai hasil yang diinginkan.

Hasil penelitian berdasarkan wawancara dengan salah satu pegawai Dinas Lingkungan Hidup Kabupaten Bungo terkait dengan proses perencanaan menunjukkan bahwa proses perencanaan yang dilakukan oleh Dinas Lingkungan Hidup Kabupaten Bungo dan bekerja sama dengan Satpol PP sudah terlaksana cukup baik. Hal tersebut terlihat dari telah dilaksanakannya seluruh proses perencanaan yang ada yaitu penentuan tujuan dalam kegiatan, penentuan kebijakan kegiatan terkait dengan pengelolaan sampah, membuat kegiatan dan menentukan metode prosedur serta waktu dalam pelaksanaan kegiatan, semuanya sudah diatur dan melalui proses perencanaan yang sangat baik, namun dalam pelaksanaannya masih terdapat beberapa kendala atau masalah dan kekurangan dimana tidak adanya petunjuk pelaksanaan maupun petunjuk teknis yang seharusnya menjadi pedoman pelaksanaan dari kegiatan ini.Dalam hal proses perencanaan juga harus dibuat perencanaan terkait dengan perencanaan penyediaan tempat sampah yang ada dilingkungan masyarakat setempat.

\section{Organizing (Pengorganisasian)}

Pengorganisasian tidak dapat diwujudkan tanpa ada hubungan dengan yang lain dan tanpa menetapkan tugas-tugas tertentu untuk masing-masing unit. Pengorganisasian ini adalah terkait dengan penentuan, pengelompokkan, dan penyusunan macam-macam kegiatan yang diperlukan untuk mencapai tujuan, penempatan orang-orang (pegawai), terhadap kegiatan-kegiatan ini, penyediaan faktor-faktor fisik yang cocok bagi keperluan kerja dan penunjukkan hubungan wewenang, yang dilimpahkan terhadap setiap orang dalam hubungannya dengan pelaksanaan setiap kegiatan yang diharapkan.

Hasil penelitian terkait dengan proses pengorganiasasian menunjukkan bahwa proses pengoranisasian yang dilakukan oleh Dinas Lingkungan Hidup Kabupaten Bungo sudah terlaksana cukup baik. Hal tersebut terlihat dari telah dilaksanakannya seluruh proses pengorganisasian yang ada yaitu terkait dengan mengetahui tujuan oganisasi yang ingin dicapai, penentuan kegiatan-kegiatan yang akan dilaksanakan, pengelompokan kegiatan-kegiatan, pendelegasian wewenang, rentang kendali, peranan perorangan, tipe organisasi dan struktur organisasi. Namun dalam pelaksanaannya proses pengorganisasian yang dilakukan oleh Dinas Lingkungan Hidup Kabupaten Bungo dalam pengelolaan. Persampahan ini masih terdapat masalah yaitu kurangnya koordinasi antar sesama bidang dalam pelaksanaan kegiatan yang ada. Hal tersebut terjadi karena pengelompokan kegiatan kepada bidang yang sesuai tupoksinya. Jadi kegiatan yang ada ini langsung diserahkan kepada bidang-bidang yang sesuai dengan tupoksinya sehingga tidak ada lagi koordinasi antar bidang dalam pelaksanaan kegiatan tersebut selanjutnya. Sehingga dalam kegiatan pengelolaan sampah pun menjadi terhambat.Selanjutnya masih kurangnya kualitas sumber daya manusia yang ada membuat peranan perorangan dalam pelaksanaan kegiatan masih belum berjalan efektif. 


\section{Actuating (Pelaksanaan/Penggerakan)}

Fungsi manajemen yang dimulai dari perencanaan sampai pengorganisasian tanpa adanya fungsi pelaksanaan yang baik, maka fungsi manajemen tersebut belum bisa dikatakan baik. Apapun program dan tujuan dari suatu organisasi pasti membutuhkan yang namanya proses pelaksanaan atau penggerakan. Penggerakan adalah membangkitkan dan mendorong semua anggota kelompok agar supaya berkehendak dan berusaha dengan keras untuk mencapai tujuan dengan ikhlas serta serasi dengan perencanaan dan usahausaha pengorganisasian dari pihak pimpinan.

Adapun mekanisme terkait dengan pelaksanaan pengangkutan sampah bahwa pengangkutan sampah dilakukan dalam bentuk membawa sampah dari sumber dan/atau dari TPS atau dari TPST menuju ke TPA. Pengangkutan sampah dari TPS dan/atau dari TPS 3R ke TPA atau TPST dilakukan oleh pemerintah daerah dengan menyediakan alat angkut sampah terpilah paling sedikit 5 (lima) jenis sampah dan pembuangan tidak mencemari lingkungan. Sampah yang telah ditempatkan di TPS kemudian diangkut dengan kendaraan sampah ke tempat pembuangan/pemusnahan sampah. Termasuk juga dengan jam atau waktu pengangkutan sampah dari TPS termasuk jalur-jalur pengangkutan sampah ke TPA.

Hasil penelitian terkait dengan proses pelaksanaan atau penggerakan menunjukkan bahwa pada tahap pelaksanaan dalam pengelolaan sampah yang dilakukan oleh Dinas lingkungan Hidup Kabupaten Bungo khususnya di Kecamatan Rimbo Tengah sudah terlaksana dengan cukup baik, yaitu terkait dengan tersedianya tempat-tempat penampungan sampah sementara yang ada disekitar lingkungan masyarakat. Hal tersebut sudah disediakan oleh pihak dinas terkait yaitu Dinas Lingkungan Hidup Kabupaten Bungo. Tetapi dalam menyediakan tempat penampungan sampah sementara yang ada disekitar lingkungan masyarakat tersebut menimbulkan permasalahan baru, yaitu terkait dengan proses pengambilan sampah oleh pegawai yang bertugas tidak sesuai dengan waktu yang telah ditetapkan. Sehingga sampah yang dibuang oleh masyarakat ke tempat pembuangan sampah sementara tersebut menimbulkan bau yang sangat menyengat, dan dapat menggaanggu kenyamanan masyarakat yang lewat di tempat pembuangan sampah sementara tersebut, karena penyediaan tempat sampah sangat dekat dengan jalan yang dilalui oleh masyarakat.

Hal tersebut dapat dirasakan oleh salah satu warga yang tinggal disekitar lokasi perumahan warga di Sungai Buluh Indah di Kecamatan Rimbo Tengah, saat diwawancarai salah satu warga tersebut (mas alip) menyatakan bahwa: sampah perumahan yang ada disekitar lingkungan tersebut terkadang diambil oleh petugas pengambil sampah tidak sesuai dengan waktu yang sudah ditentukan, seharusnya sampah yang sudah terkumpul akan diambil oleh petugas pada hari senin dan jum'at dalam waktu seminggu, awalawalnya petugas pengambil sampah tersebut mengambil sampah tepat pada waktunya, tetapi tidak berlangsung lama, dan sekarang mereka mengambil sampah terkadang tidak tahu dengan hari yang sudah ditentukan, terkadang diambil dua minggu sekali, sehingga kalau sampah perumahan yang terlalu lama mengendap, akan menimbulkan bau yang kurang sedap dan akan mengganggu kenyamanan masyarakat.

Terkait pada tahap pelaksanaan tersebut dalam pengambilan sampah, maka perlu juga dorongan atau pemberian motivasi kepada petugas kebersihan. Proses pemberian motivasi yang dilakukan oleh Dinas Lingkungan Hidup Kabupaten Bungo sudah terlaksana dengan baik. Hal tersebut terlihat dari proses pemberian motivasi yang ada yaitu berupa penghargaan (reward) dan hukuman (punishment). Karena pemberian motivasi kepada petugas kebersihan merupakan suatu hal yang sangat penting, supaya dalam proses pelaksanaannya bisa terlaksana dengan baik dan agar tujuan dari awal sesuai dengan perencanaan dapat tercapai.

\section{Controlling (Pengawasan)}

Pengawasan mempunyai peranan atau kedudukan yang penting sekali dalam manajemen, mengingat mempunyai fungsi untuk menguji apakah pelaksanaan kerja teratur tertib, terarah atau tidak. Dengan demikian kontrol mempunyai fungsi untuk mengawasi segala kegaiatan agar tertuju kepada sasarannya, sehingga tujuan yang telah ditetapkan dapat tercapai.

Pengawasan dapat dirumuskan sebagai proses penentuan apa yang harus dicapai yaitu standard, apa yang sedang dilakukan yaitu pelaksanaan, menilai pelaksanaan, dan bila mana perlu melakukan perbaikanperbaikan, sehingga pelaksanaan sesuai dengan rencana, yaitu selaras dengan standard (ukuran).

Hasil penelitian terkait dengan pengawasan menunjukkan bahwa proses pengawasan yang dilakukan oleh Dinas Lingkungan Hidup Kabupaten Bungo sudah terlaksana cukup baik. Hal tersebut terlihat dari telah terlaksananya proses pengawasan yang ada yaitu pengawasan langsung seperti pengecekan langsung pelaksanaan kegiatan di lapangan maupun pengawasan tidak langsung seperti laporan realisasi dari setiap kegiatan yang ada secara rutin. Namun dalam proses pengawasan ini masih terdapat masalah, yaitu dalam proses pengawasan tidak secara rutin mengawasi para petugas yang bertugas untuk mengambil atau 
mengangkut sampah, sehingga sampah pun menjadi menumpuk di tempat pembuangan sementara. Terkait dengan laporan, salah satu masyarakat juga pernah melaporkan ke ketua RT setempat terkait dengan pengambilan sampah yang tidak sesuai dengan waktu yang telah ditentukan, kemudian dari pihak ketua RT akan melaporkan kepada pihak Dinas Lingkungan Hidup. Hal tersebut juga termasuk dalam bentuk pengawasan yang tidak langsung oleh pihak dinas, tetapi tetap dalam pengawasan oleh pihak dinas karena adanya laporan yang dilakukan oleh masyarakat.

Proses pengawasan ini yang dilakukan oleh Dinas Lingkungan Hidup merupakan suatu hal yang sangat penting, karena menyangkut dengan semua kegiatan-kegaitan yang telah dilakukan, dan agar semua apa-apa yang dilakukan mulai dari perencanaan sampai pelaksanaannya dapat berjalan sesuai dengan tugasnya masing-masing, dan proses pengawasan ini juga akan memperbaiki dimana letak kesalahannya jika terdapat kesalahan-kesalahan yang tidak sesuai dengan standar operasional prosedurnya.

Pemantauan atau pengawasan secara berkala oleh petugas pengawas yang dibentuk pemerintah sangat diperlukan. Tidak hanya itu, peran aktif masyarakat juga diperlukan dalam pemantauan agar pengelolaan sampah dapat berjalan dengan baik. Mekanisme pemantauan ini dapat diatur oleh peraturan daerah setempat dengan sistem reward dan punishment agar dapat menjadi pedoman dan pembelajaran bagi masyarakat yang ada di daerah setempat. Pemantauan atau pengawawasan dimaksudkan untuk meminimalisir terjadinya masalah akibat sampah. Evaluasi juga merupakan komponen penting untuk terjaminnya keberlangsungan pengelolaan sampah yang baik. Evaluasi dilakukan oleh pemerintah Kecamatan Rimbo Tengah Kabupaten Bungo agar didapatkan gambaran mengenai persampahan pada tahun sebelumnya. Hasil dari evaluasi ini dapat menjadi bagan untuk perencanaan kebutuhan pengelolaan sampah pada tahun selanjutnya.

\section{KESIMPULAN DAN SARAN}

Berdasarkan uraian, hasil dan pembahasan di atas terkait tentang manajemen persampahan di Kecamatan Rimbo Tengah Kabupaten Bungo dapat ditarik kesimpulan bahwa manajemen persampahan di Kecamatan Rimbo Tengah Kabupaten Bungo oleh Dinas Lingkungan Hidup Kabupaten Bungo sudah terlaksana dengan baik. Hal tersebut dapat dilihat dari penerapan perspektif manajemen yang berperan penting dalam keseluruhan proses pengelolaan persampahan mulai dari perencanaan (Planning), pengorganisasian (Organizing), pelaksanaan/penggerakan (Actuating) dan pengawasan (Controlling). Namun dalam proses pengelolaan persampahan oleh Dinas Lingkungan Hidup Kabupaten Bungo ini masih terdapat beberapa masalah dan kekurangan dalam proses manajemennya yaitu pada proses pelaksanaan atau penggerakan dan proses pengawasan, karena masih ada terdapat petugas yang mengambil sampah di tempat pembungan sampah sementara tidak sesuai dengan waktu yang sudah ditentukan diawal, sehingga menimbulkan bau yang sangat menyengat dan mengganggu kenyamanan masyarakat setempat khususnya di Kecamatan Rimbo Tengah. Kemudian dalam proses pengawasan yang dilakukan oleh Dinas Lingkungan Hidup Kabupaten Bungo juga terdapat sedikit masalah yaitu terkait proses pengawasan tidak secara rutin dilakukan oleh dinas terkait yaitu Dinas Lingkungan Hidup Kabupaten Bungo.

Saran yang dapat peneliti berikan adalah dalam rangka peningkatan pengelolaan sampah yang di Kecamatan Rimbo Tengah, pemerintah daerah melalui Dinas Lingkungan Hidup Kabupaten Bungo agar bisa lebih meningkatkan lagi pengembangan metode pengelolaan sampah dan sosialisasi kepada masyarakat untuk melaksanakan 3R yaitu Reuse berarti menggunakan kembali sampah yang masih dapat digunakan untuk fungsi yang sama ataupun fungsi lainnya. Reduce berarti mengurangi segala sesuatu yang mengakibatkan sampah. Dan Recycle berarti mengolah kembali (daur ulang) sampah menjadi barang atau produk baru yang bermanfaat. Disarankan juga bahwa pemerintah daerah menyediakan dan mengoperasikan TPA dengan melakukan dengan pemilihan lokasi sesuai rencana tata ruang wilayah (RTRW), menyusun analisis biaya dan teknologi, menyusun rencana teknis, sehingga dapat memperbaiki perilaku masyarakat dalam membuang sampah sehingga jumlah sampah yang dihasilkan tidak membahayakan bagi kesehatan dan lingkungan. Selanjutnya yang dapat peneliti sarankan adalah perlu ditingkatkan lagi kedisiplinan waktu pegawai menjalankan pekerjaannya, yaitu terkait dengan proses pelaksanaan dalam pengambilan sampah, agar tidak terjadi penumpukan sampah disekitar lingkungan masyarakat. Kemudian dalam meningkatkan semangat kerja petugas dalam pengelolaan sampah, maka perlu diberikan motivasi berupa penghargaan (reward) dan hukuman (punishment). Dan hendaknya harapan ke depannya manajemen persampahan di Kecamatan Rimbo Tengah Kabupaten Bungo lebih baik dan baik lagi agar lingkungan tetap menjadi bersih dari persampahan. 


\section{DAFTAR PUSTAKA}

\section{Buku}

Aziz, Anton Mulyono dan Maya Irjayanti. 2014. Manajemen. Mardika Group: Bandung.

Azwar, A. 1990. Pengantar Ilmu Kesehatan Lingkungan. Yayasan Mutiara: Jakarta.

Hasibuan, Malayu SP. 2014. Manajemen Sumber Daya Manusia, Edisi Revisi. PT.Bumi Aksara: Jakarta.

Lilis, Sulastri. 2014. Manajemen Sebuah Pengantar Sejarah, Tokoh, Teori, dan Praktik. La Goods Publishing: Bandung.

Manik, K.E.S. 2003. Pengelolaan Lingkungan Hidup. Djambatan: Jakarta.

Mochtar M. 1987. Kesehatan Masyarakat Yayasan Karya Dharma IIP. Jakarta.

Mulyadi, Muhammad. 2012. Penelitian Kuantitatif dan Kualitatif serta Praktek Kombinasinya dalam Penelitian Sosial. Jakarta: Publica Institute.

Nurul dan Mubarak, Wahid Iqbal. 2009. Ilmu Kesehatan Masyarakat Teori dan Aplikasi. Salemba Medika: Jakarta.

Silalahi, Ulber. 2011. Asas-Asas Manajemen. Refika Aditama: Bandung.

Sukarna. 2011. Dasar-Dasar Manajemen. CV. Mandar Maju: Bandung.

Sugiyono, 2010. Metode Penelitian Administrasi. Alfabeta. Jakarta.

Soemirat, Juli. 1994. Kesehatan Lingkungan. Mutiara Sumber Widya: Jakarta.

R.Terry, George dan Leslie W.Rue. 2010. Dasar-Dasar Manajemen. Bumi Aksara: Jakarta.

R.Terry, George. 2006. Prinsip- Prinsip Manajemen. Bumi Aksara: Jakarta.

\section{Jurnal}

Mohamad Rizal. 2011. Analisis Pengelolaan Persampahan Perkotaan (Sudi kasus pada Kelurahan Boya Kecamatan Banawa Kabupaten Donggala). Jurnal SMARTek. Vol. 9 No. 2.

Muchammad Zamzami Elamin, Kartika Nuril Ilmi, Tsimaratut Tahrirah, Yudhi Ahmad Zarnuzi, Yanuar Citra Suci, Dwi Ragil Rahmawati, Rizky Kusumawardhani, Dimas Mahendra Dwi P., Rizqi Azizir Rohmawati, Pandhu Aji Bhagaskoro, Ismi Fuatjia Nasifa. 2018.Analisis Pengelolaan Sampah Pada Masyarakat Desa Disanah Kecamatan Sreseh Kabupaten Sampang.Jurnal Kesehatan Lingkungan. Vol.10. No.4.

Putri Nilam Sari. 2016.Analisis Pengelolaan Sampah Padat Di Kecamatan Banuhampu Kabupaten Agam. Jurnal Kesehatan Masyarakat Andalas. Vol. 10. No. 2.

Siti Rizka Mulyani, Yoserizal dan Roni Ekha Putera. 2018. Manajemen Persampahan di Kota Bukittinggi.Jurnal SAWALA. Vol 6. No 2.

Viradin Yogiesti, Setiana Hariyani, Fauzul Rizal Sutikno. 2010. Pengelolaan Sampah Terpadu Berbasis Masyarakat Kota Kediri. Jurnal Tata Kota dan Daerah Vol. 2, No. 2.

\section{Perundang-Undangan}

Undang-Undang Nomor 23 Tahun 1997 tentang Pengelolaan Lingkungan Hidup.

Undang-Undang Nomor 18 Tahun 2008 tentang pengelolaan sampah.

Peraturan Daerah Kabupaten Bungo Nomor 6 tahun 2015 Tentang Pengelolaan sampah. 